\title{
Mitochondrial DNA analysis of North Pacific swordfish Xiphias gladius population structure
}

\author{
J. M. Grijalva-Chon ${ }^{1, *}$, K. Numachi ${ }^{2, * *}$, O. Sosa-Nishizaki ${ }^{1}$, J. de la Rosa-Velez ${ }^{3}$ \\ ${ }^{1}$ Centro de Investigación Científica y de Educación Superior de Ensenada, Laboratorio de Ecología Pesquera, PO Box 2732. \\ Ensenada, Baja California, México \\ ${ }^{2}$ University of Tokyo, Ocean Research Institute, Minamidai 1-15-1, Nakano-ku, Tokyo 164, Japan \\ ${ }^{3}$ Universidad Autónoma de Baja California, Facultad de Ciencias Marinas, PO Box 453, Ensenada, Baja California, México
}

\begin{abstract}
Restriction fragment length polymorphism (RFLP) analysis of mitochondrial DNA (mtDNA) was used to investigate population structure of the North Pacific swordfish Xiphias gladius. Samples of $X$ gladius from the western $(n=47)$, central $(n=42)$, and eastern $(n=59)$ Pacific were examined for mtDNA variation using 17 six-base pair restriction endonucleases. A total of 27 composite mtDNA genotypes were revealed, and $50 \%$ or more of individuals from each area shared the most common composite genotype. Pooled nucleon diversity and nucleotide diversity were 0.637 and 0.0019 , respectively, and the mean nucleotide sequence divergence among genotypes was $0.88 \%$ ( $\operatorname{rank} 0.11$ to $2.80 \%$ ). Both nucleotide differences between populations and Gst analysis revealed low values. No significant geographic variation in genotypic frequencies was revealed by $G$-test and Monte Carlo randomization analysis with 1000 replicates. This suggests that there is sufficient gene flow across the North Pacific to prevent genetic differentiation, and is consistent with the interpretation that North Pacific swordfish represent a single genetic stock.
\end{abstract}

KEY WORDS: Swordfish - Xiphias gladius - Genetic population structure - Stock discrimination mtDNA analysis - Restriction fragment length polymorphism analysis - Pacific Ocean

\section{INTRODUCTION}

The swordfish Xiphias gladius is a pelagic fish with a worldwide distribution (Nakamura 1983). It is an esteemed food fish, known for its white, firm flesh, mild flavor, and high flesh-to-bone ratio (Sakagawa 1989). Major markets for swordfish include western Europe, Japan, and the U.S. (Sakagawa 1989). In Japan swordfish is expensive, and is utilized as 'sashimi' or sold as fillets to be broiled or baked (Ueyanagi et al. 1989). Between 1975 and 1987, $43 \%$ of

Present addresses:

- Universidad de Sonora, Centro de Investigaciones Científicas y Tecnológicas, Rosales y Niños Héroes s/n. Hermosillo, Sonora, México

- Tokai University, Faculty of Marine Science and Technology, Orido 3-20-1, Shimizu, Shizuoka 424, Japan the total global catch was taken in the Pacific Ocean (Sosa-Nishizaki 1990).

To assess the status of swordfish in the Pacific Ocean, several authors have attempted to delimit boundaries between putative stocks. Skillman (1989a) suggested that there was a single Pacific-wide stock. Bartoo \& Coan (1989) carried out a fishery analysis based on the existence of 1 to 3 stocks. Sakagawa (1989) mentioned 5 areas of high swordfish abundance related with frontal zones, and Sosa-Nishizaki (1990) suggested the existence of 4 fishery units across the Pacific. These studies were based on the analysis of the distribution of fishery catches, and the need for other stock identification methods has been highly recommended (Skillman 1989b).

The usefulness of mitochondrial DNA (mtDNA) in resolving stock structure in marine fishes has been demonstrated (Ovenden 1990). In vertebrates, mtDNA. is a closed circular molecule of 15000 to 18000 base 
pairs (bp). Each molecule encodes for 2 ribosomal RNAs, 22 transfer RNAs, 13 proteins, and the replication or D-loop region (Ferris \& Berg 1987). Although mtDNA comprises less than $1 \%$ of the total genome in each cell, it has 2 very important characteristics: a high rate of evolution, and a maternal mode of transmission. The fact that mtDNA genes evolve 5 to 10 times faster than their nuclear counterparts provides an amplified vision of subpopulation differentiation (Brown et al, 1979).

There are few studies of swordfish population genetics. Alvarado-Bremer (1992) analysed the whole mtDNA molecule by RFLP (restriction fragment length polymorphism) from a small number of individuals caught in the Atlantic Ocean. He proposed the existence of a population structure on the basis of the sequence divergence figures obtained (>1.6\%), but the average was low, ca $0.79 \%$. On a larger scale, Magoulas et al. (1992), working also with the whole mtDNA molecule, found evidence of differentiation between swordfish from the Mediterranean Sea and the Atlantic Ocean. On the other hand, Chow (1992), using RFLP analysis of mtDNA cytochrome $b$ gene, found no evidence of differentiation among swordfish from the Pacific and the Indo-Pacific Oceans. Finnerty $\&$ Block (1992) sequenced the mtDNA cytochrome $b$ in a small number of swordfish from the Atlantic, Pacific, and Mediterranean and found low intraspecific variation. On the other hand, allozyme analysis for swordfish has not been reported in the literature.

The objective of this study was to measure intraspecific genetic variability and test genetic homogeneity in the North Pacific swordfish.

\section{MATERIALS AND METHODS}

A total of 148 swordfish were collected from 3 areas in the North Pacific (Fig 1). In the western Pacific

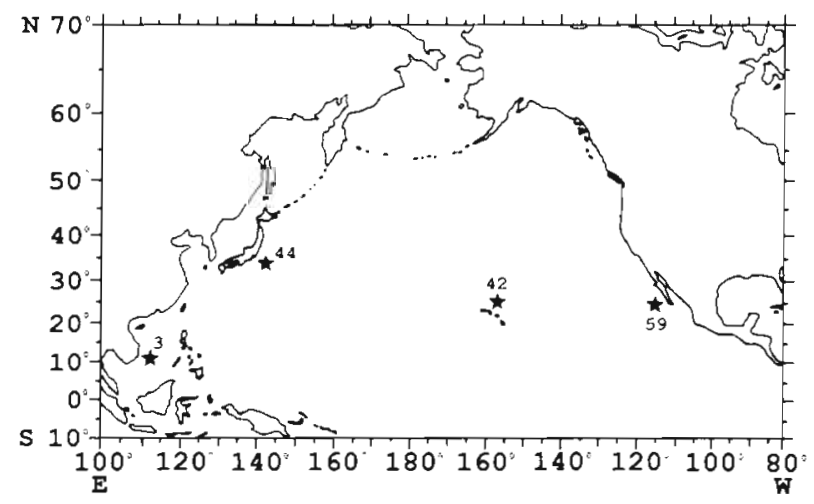

Fig. 1. North Pacific showing the collection sites of swordfish samples
(Japan and China Sea), 47 fishes were caught by commercial fleet using long lines during January to March 1992. In the central Pacific (Hawaii), 42 fishes were collected in a scientific survey in April-May 1992, also using long lines. In the eastern Pacific (Baja California, Mexico), 59 fishes were caught by commercial fleet using drift gillnets from November 1991 to February 1992. Samples from the western Pacific were preserved at low temperature $\left(-70^{\circ} \mathrm{C}\right)$; those from the central and eastern Pacific were preserved in ethanol.

Total DNA was isolated from 50 to $100 \mathrm{mg}$ of skeletal muscle. Samples were homogenized in $500 \mu$ l of STE buffer $(10 \mathrm{mM}$ Tris- $\mathrm{HCl} \mathrm{pH} 8,10 \mathrm{mM} \mathrm{NaCl}, 50 \mathrm{mM}$ EDTA). Cellular membranes were lysed with $25 \mu \mathrm{l}$ of $20 \%$ SDS, and $25 \mu$ of proteinase $K$ solution $(20 \mathrm{mg}$ $\mathrm{ml}^{-1}$ ) was used to denature protein molecules at $37^{\circ} \mathrm{C}$ overnight. After treatment with phenol-chloroformisoamylalcohol, DNA was precipitated with ethanol. The pellet was redissolved in $200 \mu \mathrm{l}$ of TE buffer (10 mM Tris- $\mathrm{HCl} \mathrm{pH} 7.5,1 \mathrm{mM}$ EDTA).

DNA samples were screened with 17 six-base pair restriction endonucleases (ApaI, BamHI, BglI, BglII, DraI, EcoRI, EcoRV, HindIII, KpnI, PstI, PvulI, SacI, SaclI, Sall, SmaI, XbaI, XhoI). Ten to twelve units of enzyme were used in each reaction mixture, following manufacturer's instructions (Takara Shuzo, Toyobo, and New England Biolabs). Reactions were stopped with addition of $2 \mu$ loading dye $(7 \mathrm{M}$ urea, $0.1 \% \mathrm{BPB}$, $10 \mathrm{mM}$ EDTA, 50\% sucrose). DNA fragments were separated by size in horizontal $0.8 \%$ agarose gels in $1 \times$ TAE buffer ( $50 \times: 2 \mathrm{M}$ Tris- $\mathrm{HCl}$ pH 8, $1 \mathrm{M}$ acetic acid, $50 \mathrm{mM}$ EDTA) run at 75 to $80 \mathrm{~V}(45 \mathrm{~mA})$ for $2 \mathrm{~h}$. Lambda DNA digested with HindIII was used as a size standard. After electrophoresis, fragments were transferred to a nylon membrane (Hybond-N, Amersham) by Southern blotting using a vacuum device and the DNA was bound to the membrane with UV light (Sambrook et al. 1989).

Chum salmon Oncorhynchus keta closed circular mtDNA, purified by $\mathrm{CsCl}$ gradient centrifugation according to Numachi et al. (1990), and labeled with digoxigenin-dUTP by random priming following the manufacturer's instructions (Boehringer Mannheim GmbH), was used as the probe.

The intrapopulational genetic variability was measured in 2 ways: the nucleon diversity (Nei \& Tajima 1981), and the nucleotide diversity (Nei 1987). In both cases, the standard error was calculated according to Nei (1987). These diversities were calculated for each sampled area and for pooled areas. The number of net nucleotide substitutions among sampled areas was estimated according to Nei (1987). In order to test homogeneity of haplotype frequencies among samples, both $G$-test (Sokal \& Rohlf 1981) and the Monte Carlo randomization approach (Roff \& Bentzen 1989) 
with 1000 replications were used. Percentage of sequence divergence among haplotypes was calculated from restriction-fragment patterns using the length-differences method (Nei 1987). Gst analysis of gene differentiation among samples (Nei 1987) was calculated considering haplotypes as alleles.

\section{RESULTS}

Of the 17 restriction enzymes used, 3 (BamHI, XhoI and $E c o R I)$ did not cut swordfish mtDNA. Six enzymes (XbaI, HindIII, EcoRV, PstI, BglII and SalI) cleaved the molecule in 2 or more fragments, but revealed no variation. Eight enzymes, BglI, Apal, Dral, SacI, KpnI, PvuII, SacIl and SmaI, showed 2 to 6 different restriction-fragment patterns (a table of restriction fragment patterns is available upon request). The size of the swordfish mtDNA molecule was estimated to be 16423 $\pm 740 \mathrm{bp}$. In this estimation we did not take into account DraI because small or commigrating bands

Table 1. Xiphias gladius. Distribution of haplotypes in North Pacific swordfish samples. Letters in composite genotypes denote, from left to right, digestion patterns for: KpnI, BglI, Dral, PvuII, ApaI, Smal, Sacl, Sacll

\begin{tabular}{|c|c|c|c|c|}
\hline Haplotype & $\begin{array}{l}\text { Composite } \\
\text { genotype }\end{array}$ & Eastern & Central & Western \\
\hline 1 & AAAAAAAA & 39 & 21 & 28 \\
\hline 2 & AAAAAABA & 5 & 2 & 5 \\
\hline 3 & AAACABBA & 3 & 3 & 1 \\
\hline 4 & AAAAABBA & 1 & 1 & 2 \\
\hline 5 & AAAAAEAA & 1 & 2 & \\
\hline 6 & AAAAAACA & 1 & 1 & \\
\hline 7 & AABAAADA & 1 & 1 & \\
\hline 8 & AABABAAA & 1 & & \\
\hline 9 & AADABAAA & 1 & & \\
\hline 10 & ACAAAAAA & 1 & & \\
\hline 11 & AEAAABBA & 1 & & \\
\hline 12 & AAAABAAA & 1 & & \\
\hline 13 & AAAACAAA & 1 & & 1 \\
\hline 14 & AABAAABA & 1 & & 1 \\
\hline 15 & AAAADAAA & 1 & & 1 \\
\hline 16 & AABAAACA & & 1 & 1 \\
\hline 17 & AABAAAAA & & 2 & 3 \\
\hline 18 & ADAAAAAA & & 1 & 2 \\
\hline 19 & AAAAFAAA & & 1 & \\
\hline 20 & $\mathrm{AAABCAAB}$ & & 1 & \\
\hline 21 & ABAAAAAA & & 1 & \\
\hline 22 & ACACABBA & & 1 & \\
\hline 23 & AACAAAAA & & 1 & \\
\hline 24 & CAAAAAAA & & 1 & \\
\hline 25 & BAAAAAAA & & 1 & \\
\hline 26 & AADAAABA & & & 1 \\
\hline 27 & AFAAAAAA & & & 1 \\
\hline \multicolumn{2}{|c|}{ No. of individuals } & 59 & 42 & 47 \\
\hline \multicolumn{2}{|c|}{ No. of genotypes } & 15 & 17 & 12 \\
\hline
\end{tabular}

Table 2. Nucleon and nucleotide diversity in 5 billfish species. SE: standard error

\begin{tabular}{|c|c|c|c|c|}
\hline $\begin{array}{c}\text { Species } \\
\text { Area }\end{array}$ & $\begin{array}{l}\text { Nucleon } \\
\text { diversity }\end{array}$ & SE & $\begin{array}{c}\text { Nucleotide } \\
\text { diversity }(\%)\end{array}$ & SE \\
\hline \multicolumn{5}{|c|}{ Swordfish Xiphias gladius ${ }^{d}$} \\
\hline Eastern & 0.56 & 0.05 & 0.17 & 0.15 \\
\hline Central & 0.75 & 0.08 & 0.26 & 0.23 \\
\hline Western & 0.63 & 0.17 & 0.16 & 0.15 \\
\hline Pooled & 0.64 & 0.02 & 0.19 & 0.13 \\
\hline \multicolumn{5}{|c|}{ Striped marlin Tetrapturus audax ${ }^{\mathrm{D}}$} \\
\hline Pacific & 0.74 & & 0.54 & \\
\hline \multicolumn{5}{|c|}{ Blue marlin Makaira nigricans ${ }^{\mathrm{b}}$} \\
\hline Atlantic-Pacific & 0.86 & & 1.99 & \\
\hline Pacific & 0.45 & & 0.33 & \\
\hline \multicolumn{5}{|c|}{ Sailfish Istiophorus platypterus ${ }^{b}$} \\
\hline Atlantic-Pacific & 0.62 & & 0.87 & \\
\hline Pacific & 0.00 & & 0.00 & \\
\hline \multicolumn{5}{|c|}{ White marlin Tetrapturus albidus ${ }^{\text {b }}$} \\
\hline Atlantic & 0.70 & & 0.35 & \\
\hline \multicolumn{5}{|c|}{ 'This study } \\
\hline${ }^{\mathrm{b}}$ Graves \& McDow & well $(1992$ & & & \\
\hline
\end{tabular}

could not be detected. In the PvuII's C pattern we inferred a commigrating band by extra-intense color. Although small fragments could not be visualized, the patterns demonstrated were assumed to be due to single nucleotide substitutions.

A total of 27 mtDNA haplotypes were discriminated on the basis of restriction patterns of polymorphic enzymes. Only 4 haplotypes were common to all 3 areas sampled, and $\geq 50 \%$ of individuals in each area possessed the most common haplotype (Table 1). Other haplotypes occurred in very low frequencies. Both $G$-test and Monte Carlo randomizations indicated homogeneity of genotypic frequencies across areas ( $p>0.1$ in both cases).

Nucleon and nucleotide diversities are shown in Table 2; pooled values were 0.64 and 0.0019 , respectively. Percent sequence divergence among haplotypes ranged from 0.11 to 2.80 , averaging $0.88 \pm 0.47$. Pairwise number of net nucleotide substitutions were -0.0016 for east vs west $t_{i}-0.0020$ for east vs central; and -0.0019 for central vs west. Estimated mean Gst was 0.046 .

\section{DISCUSSION}

The size of the swordfish mtDNA molecule is within the range reported for other fishes, and the sequence of divergence values among haplotypes corresponds to 
figures for intraspecific level in marine fishes (Becker et al. 1988, Billington \& Hebert 1991). From our data, we can not reject the hypothesis of genetic homogeneity in North Pacific swordfish. Differences in genotypic frequencies reveal population structure (Chakraborty \& Leimar 1987). In this sense, the population signal in a structured population may be defined by the dominant genotype. The North Pacific swordfish is not structured (according to our data), and the frequency analysis of haplotypes did not show statistically significant differences. Besides this, only $4.6 \%$ of total diversity is attributable to genetic differences among populations. Furthermore, the negative figures of net nucleotide substitutions among areas indicate a very close relationship among them (Nei \& Tajima 1981). These results supports the hypothesis of genetic homogeneity in North Pacific swordfish.

In the absence of reproductive isolation by geographic barriers, or differences of reproductive periods, the swimming capacity of fishes can overcome isolation by distance in large oceanic areas. The genetic similarity found in albacore Thunnus alalunga and skipjack tuna Katsuwonus pelamis between the Pacific and Atlantic Oceans by Graves et al. (1984) and Graves \& Dizon (1989) could be explained by their high vagility. This high migratory capacity in tunas has been demonstrated by tagging studies (Joseph et al. 1988).

Billfishes also display a high vagility. A notable case is one blue marlin Makaira nigricans tagged in waters off Baja California and retrieved near New Zealand, almost $6000 \mathrm{~km}$ away (Pepperell 1989). Although there are no results for swordfish from large scale tagging programs in the Pacific Ocean, based on the movement of the species in the Atlantic Ocean (Miyake \& Rey 1989) we suppose that they can move over great distances.

Scott \& Tibbo (1968) suggested that swordfish feed over a wide depth range. This behaviour was confirmed by acoustic telemetry and echograms (Carey \& Robinson 1981, Carey 1989), and apparently swordfish feed on slope waters (Carey 1989). If this behaviour is the rule then the swordfish mobility would be limited on an ocean scale and structuring of the population would be expected. However, our data suggest enough gene exchange to prevent genetic structuring.

Graves \& McDowell (1992) analyzed the genetic population structure of billfishes, finding high levels of stock structure in inter-ocean comparisons for blue marlin and sailfish Istiophorus platypterus. For Pacific striped marlin Tetrapturus audax they found high variation, suggesting more than one population. Among billfishes, swordfish have low nucleotide diversity (Table 2), but this comparison must be taken with caution because different numbers of restriction endonucleases were used.
Like blue marlin and sailfish, swordfish may be structured at an inter-ocean level. This is suggested by the differences in Dral results from Alvarado-Bremer (1992), and EcoRV, Bgll, and PvuII results from Magoulas et al. (1992). We believe that a comparative study using the same enzymes could show interesting results. A further analysis including South Pacific swordfish must be done in order to obtain a complete picture of the population structure of this resource in the Pacific Ocean.

The population genetic structure is a fundamental piece of information for any species that requires management (Baverstock \& Moritz 1990). The Pacific swordfish population has been previously divided into several areas (stocks) considering only fishery data. However, it is not possible to delimit administrative boundaries with different management strategies because fishing pressure in one area may affect another area. In this way, the swordfish management programs, at least in the North Pacific, must include an international agreement among the nations involved in this fishery, considering the new data on population genetic structure.

Acknowledgements. We thank the following people and institutions for help with sampling activities or sharing samples: R. de la Rosa-Pacheco (Cámara Nacional de la Industria Pesquera, Sección Especializada en Pesca de Pez Espada, Mexico), R. Skillman and J. Uchiyama (National Marine Fisheries Service, Honolulu Laboratory, USA), and S. Chow (National Research Institute of Far Seas Fisheries, Shimizu, Japan). Y. Akimoto and H. Suzuki deserve special thanks for help in the laboratory. K. Saitoh kindly provided an English version of his RFLP analysis software. We gratefully acknowledge J. Graves and 3 anonymous referees for their comments and suggestions on the manuscript.

\section{LITERATURE CITED}

Alvarado-Bremer, J. R. (1992). Stock differentiation of Atlantic swordfish using mitochondrial DNA analysis. ICCAT (International Commission for the Conservation of Atlantic Tunas), Madrid, Collective volume of scientific papers, SCRS/91/48, 39(2): 607-614

Bartoo, N. W. Coan, A. L. Jr (1989). An assessment of the Pacific swordfish resource. In: Stroud, R. H. (ed.) Proc. 2nd Int. Billfish Symp., Kaila-Kona, Hawaii, 1-5 August 1988, Part 1. National Coalition for Marine Conservation, Inc., Savannah, GA

Baverstock, P. R., Moritz, C. (1990). Sampling design. In: Hillis, D. M., Moritz, C. (eds.) Molecular systematics. Sinauer Associates, Inc., Sunderland, MA

Becker, I. I., Grant, W. S., Kirby, R., Robb, F. T (1988). Evolutionary divergency between sympatric species of southern African hakes, Merluccius capensis and M. paradoxus. II. Restnction enzyme analysis of mitochondrial DNA. Heredity 61: 21-30

Billington, N., Hebert, P. D. N. (1991). Mitochondrial DNA diversity in fishes and its implications for introductions. Can. J. Fish. Aquat. Sci. 48: 80-94

Brown, W. M., George, M. Jr, Wilson, A. C. (1979). Rapid evo- 
lution of animal mitochondrial DNA. Proc. Natl Acad. Sci U.S.A. 76: $1967-1971$

Carey, F. G. (1989). Further acoustic telemetry observations of swordfish. In: Stroud, R. H. (ed.) Proc. 2nd Int. Billfish Symp., Kaila-Kona, Hawaii, 1-5 August 1988, Part 2. National Coalition for Marine Conservation, Inc., Savannah, GA

Carey, F. G., Robinson, B. H. (1981). Daily patterns in the activities of swordfish, Xiphias gladius, observed by acoustic telemetry. Fish. Bull. U.S. 79: 277-292

Chakraborty, R., Leimar, O. (1987). Genetic variation within a subdivided population. In: Ryman, N., Utter, F. (eds.) Population genetics and fishery management. University of Washington Press, Seattle

Chow, S. (1992). Identification of billfish species using mitochondrial cytochrome $b$ gene fragment amplified by polymerase chain reaction. ICCAT Working Document SCRS/92/66. ICCAT (International Commission for the Conservation of Atlantic Tunas), Madrid

Ferris, S. D., Berg, W. J. (1987). The utility of mitochondrial DNA in fish genetics and fishery management. In: Ryman, N., Utter, F. (eds.) Population genetics and fishery management. University of Washington Press, Seattle

Finnerty, J. R., Block, B. A. (1992). Direct sequencing of mitochondrial DNA detects highly divergent haplotypes in blue marlin (Makaira nigricans). Mol. mar. Biol. Biotech. 1: 206-214

Graves, J. E., Dizon, A. E. (1989). Mitochondrial DNA sequence similarity of Atlantic and Pacific albacore tuna (Thunnus alalunga). Can. J. Fish. Aquat. Sci. 46: 870-873

Graves, J. E., Ferris, S. D., Dizon, A. E. (1984). Close genetic similarity of Atlantic and Pacific skipjack tuna (Katsuwonus pelamis) demonstrated with restriction endonucleases analysis of mitochondrial DNA. Mar. Biol. 79: 315-319

Graves, J. E., McDowell, J. R. (1992). Genetic analysis of billfish population structure. ICCAT Working Document SCRS/92/50. ICCAT (International Commission for the Conservation of Atlantic Tunas), Madrid

Joseph, J., Klawe, W., Murphy, P. (1988). Tuna and billfish: fish without a country. Inter-American Tuna Commission, La Jolla

Magoulas, A., Kotoulas, G., de la Serna, J. M., De Metrio, G., Tsimenides, N., Zouros, E. (1992). Genetic structure of swordfish (Xiphias gladius) populations of the Mediterranean and the eastern side of the Atlantic: analysis by mitochondrial DNA markers. ICCAT Working Document SCRS/92/84. ICCAT (International Commission for the Conservation of Atlantic Tunas), Madrid

Miyake, P. M., Rey, J. C. (1989). Status of Atlantic broadbill swordfish stocks. In: Stroud, R. H. (ed.) Proc. 2nd Int. Billfish Symp., Kaila-Kona, Hawail, 1-5 August 1988, Part 1 National Coalition for Marine Conservation, Inc., Savannah, GA

This article was submitted to the editor
Nakamura, I. (1983). Systematics of billfishes (Xiphiidae and Istiophoridae). Publ. Seto mar. biol. Lab. 28: 255-396

Nei, M. (1987). Molecular evolutionary genetics. Columbia University Press, New York

Nei, M., Tajima, F. (1981). DNA polymorphism detectable by restriction endonucleases. Genetics 97. 145-163

Numachi, K., Kobayashi, T., Chang, K., Lin, Y. (1990). Genetic identification and differentiation of the formosan landlocked salmon, Oncorhynchus masou formosanus, by restriction analysis of mitochondrial DNA. Bull. Inst. Zool. Acad sin. 29: 61-72

Ovenden, J. R. (1990). Mitochondrial DNA and marine stock assessment: a review. Aust. J. mar. Freshwat. Res. 41: $835-853$

Pepperell, J. G. (1992). Movements and variations in early year-class strength of black marlin (Makaira indica) off eastern Australia. In: Stroud, R. H. (ed.) Proc. 2nd Int. Billfish Symp., Kaila-Kona, Hawaii, 1-5 August 1988, Part 2. National Coalition for Marine Conservation, Inc., Savannah, GA

Roff, D. A., Bentzen, P. (1989). The statistical analysis of mitochondrial DNA polymorphisms: $\chi^{2}$ and the problem of small samples. Mol. Biol. Evol. 6: 539-545

Sakagawa, G. T. (1989). Trends in fisheries of swordfish in the Pacific Ocean. In: Stroud, R. H. (ed.) Proc. 2nd Int. Billfish Symp., Kaila-Kona, Hawaii, 1-5 August 1988, Part 1. National Coalition for Marine Conservation, Inc., Savannah, GA

Sambrook, J., Fritsch, E. F., Maniatis, T. (1989). Molecular cloning. A laboratory manual. Cold Spring Harbor Laboratory Press, Cold Spring Harbor, NY

Scott, W. B., Tibbo, S. N. (1968). Food and feeding habits of swordfish, Xiphias gladius, in the Western North Atlantic. J. Fish. Res. Bd Can. 25: 903-919

Skillman, R. A. (1989a). Status of Pacific billfish stocks. In: Stroud, R. H. (ed.) Proc. 2nd Int. Billfish Symp., KailaKona, Hawaii, 1-5 August 1988, Part 1. National Coalition for Marine Conservation, Inc., Savannah, GA

Skillman, R. A. (1989b). Stock identification and billfish management. In: Stroud, R. H. (ed.) Proc. 2nd Int. Billfish Symp., Kaila-Kona, Hawaii, 1-5 August 1988, Part 1. National Coalition for Marine Conservation, Inc., Savannah, GA

Sokal, R. R., Rohlf, F. J. (1981). Biometry. W. H. Freeman and Co., New York

Sosa-Nishizaki, O. (1990). A study on the swordfish Xiphias gladius stocks in the Pacific Ocean. Ph.D. thesis. University of Tokyo, Faculty of Agriculture

Ueyanagi, S., Shomura, R. S., Watanabe, Y., Squire, J. L. (1989). Trends in fisheries for billfishes in the Pacific. In: Stroud, R. H. (ed.) Proc. 2nd Int. Billfish Symp., KailaKona, Hawaii, 1-5 August 1988, Part 1. National Coalition for Marine Conservation, Inc., Savannah, GA

Manuscript first received: November 8,1993

Revised version accepted: August 8, 1994 